\title{
Injectable trace minerals (selenium, copper, zinc, and manganese) alleviate inflammation and oxidative stress during an aflatoxin challenge in lactating multiparous Holstein cows
}

R. T. Pate and F. C. Cardoso ${ }^{1}$

Department of Animal Sciences, University of Illinois, Urbana 61801

\begin{abstract}
Trace minerals are vital in the antioxidant response during oxidative stress; however, limited research is available on the effects of trace mineral supplementation during an aflatoxin (AF) challenge. The objective of the study was to determine the effects of 2 subcutaneous injections of $15 \mathrm{mg} / \mathrm{mL}$ of $\mathrm{Cu}, 5 \mathrm{mg} / \mathrm{mL}$ of $\mathrm{Se}$, $60 \mathrm{mg} / \mathrm{mL}$ of $\mathrm{Zn}$, and $10 \mathrm{mg} / \mathrm{mL}$ of Mn (Multimin 90, Multimin North America, Fort Collins, CO) given at 1 $\mathrm{mL} / 90.7 \mathrm{~kg}$ of average body weight in response to an AF challenge. Fifty-eight Holstein cows [body weight $($ mean $\pm \mathrm{SD})=734 \pm 60 \mathrm{~kg}$; days in milk $=191 \pm$ 93] were assigned to 1 of 3 treatments in a randomized complete block design. The experimental period (63 d) was divided into an adaptation phase (d 1-56) and a measurement phase (d 57-63). From d 57 to 59, cows received an AF challenge that consisted of $100 \mu \mathrm{g}$ of aflatoxin $\mathrm{B}_{1} / \mathrm{kg}$ of dietary dry matter intake (DMI) administered orally via balling gun. Treatments were saline injection and no AF challenge (NEG), saline injection and $\mathrm{AF}$ challenge (POS), and trace mineral injection and AF challenge (MM). Injections were performed subcutaneously on d 1 and 29. Milk was sampled 3 times daily from d 56 to 63, blood was sampled on d $0,56,60$, and 63 , and liver samples were taken on $\mathrm{d} 0$ and 60. Two treatment orthogonal contrasts [CONT1 (NEG vs. POS) and CONT2 (POS vs. MM)] were made. Cows in NEG had lower AF excretion in milk and greater $3.5 \%$ fat-corrected milk $(32.1 \pm 1.37$ $\mathrm{kg} / \mathrm{d})$ compared with cows in POS $(28.6 \pm 1.43 \mathrm{~kg} / \mathrm{d})$. Feed efficiencies (3.5\% fat-corrected milk/DMI, energycorrected milk/DMI, and milk/DMI) were greater for cows in NEG $(1.42 \pm 0.07,1.46 \pm 0.07$, and $1.45 \pm$ 0.07 , respectively) than cows in POS $(1.16 \pm 0.08,1.18$ \pm 0.08 , and $1.22 \pm 0.07$, respectively). Cows in POS had greater milk urea nitrogen and blood urea nitrogen than cows in MM. Liver concentrations of Se and
\end{abstract}

Received January 15, 2018.

Accepted May 3, 2018.

${ }^{1}$ Corresponding author: cardoso2@illinois.edu
Fe were greater for cows in MM compared with cows in POS. Cows in MM tended to have greater plasma glutathione peroxidase activity compared with cows in POS. An upregulation of liver GPX1 was observed for cows in POS compared with cows in MM. In conclusion, subcutaneous injection of trace minerals maintained an adequate antioxidant response when an AF challenge was present.

Key words: aflatoxin, liver, trace minerals, $\mathrm{AFM}_{1}$

\section{INTRODUCTION}

An estimated $\$ 0.11$ to $\$ 1.68$ billion is lost annually due to the effects of mycotoxins on corn crops (Mitchell et al., 2016). Mycotoxins are toxins produced by fungi growing on feed crops such as corn, with the 3 most common being aflatoxin (AF), fumonisin, and deoxynivalenol (Flores-Flores et al., 2015; Mitchell et al., 2016). Aflatoxin $\mathrm{B}_{1}\left(\mathbf{A} \mathbf{F} \mathbf{B}_{1}\right)$, an aflatoxin derivative produced by Aspergillus parasiticus and flavus, is hydroxylated and demethylated in the liver to aflatoxin $\mathbf{M}_{1}\left(\mathbf{A} \mathbf{F} \mathbf{M}_{1}\right)$ after ingestion (Kuilman et al., 2000). Aflatoxin $\mathrm{B}_{1}$ and $\mathrm{AFM}_{1}$ are classified as group 1 carcinogens by the International Agency for Research on Cancer (Liu and $\mathrm{Wu}, 2010)$; therefore, the FDA has set limits on AF concentration in feedstuffs and milk to be 20 and 0.5 $\mu \mathrm{g} / \mathrm{kg}$, respectively (Peraica et al., 1999).

Aflatoxin exposure causes adverse effects in dairy cattle, such as inappetence, immunosuppression, decreased milk production, and reproductive disorders (Abrar et al., 2013; Sulzberger et al., 2017). Aflatoxin B1 is believed to increase oxidative stress through the production of reactive oxidative species, primarily superoxide anions and hydrogen peroxides in the liver (Guengerich et al., 2001). Superoxide dismutase (SOD) is a Zn-, Mn-, and Cu-dependent enzyme linked to oxidative stress and the reduction of reactive oxidative species (Machado et al., 2014). Weatherly et al. (2018) observed greater plasma SOD concentrations for cows challenged with AF $(2.77 \mathrm{U} / \mathrm{mL})$ than cows not challenged $(1.96 \mathrm{U} / \mathrm{mL})$. Additionally, reports show that $\mathrm{AFB}_{1}$ increases bovine peripheral blood mononuclear 
cells gene expression of antioxidants, particularly SOD and glutathione peroxidase (GSH-Px), to combat the effects of oxidative stress (Bernabucci et al., 2011).

Trace minerals have an important role in immunological functions, antioxidant activity, and overall health in livestock (Spears and Weiss, 2008; Sordillo, 2013). Trace mineral status in animals varies depending on physiological status, dietary source, inflammation, and interactions among dietary constituents (Herdt and Hoff, 2011). Liver tissue often reflects trace mineral status of livestock, and low hepatic trace mineral concentration can lead to decreased inflammatory related enzyme activity (Kincaid, 2000; Herdt and Hoff, 2011). Stressful conditions, such as those experienced during the transition period, cause a decrease in DMI, which could subsequently affect trace minerals status (Drackley, 1999; Mulligan et al., 2006). Supplementing trace minerals via injection independently from DMI, has been proven to minimize stress-related issues by offering consistent trace mineral status (Vanegas et al., 2004; Machado et al., 2013). Injectable trace minerals ( $\mathrm{Zn}, \mathrm{Mn}$, Se, and $\mathrm{Cu}$ ) administered to dairy cows decreased the incidence of mastitis from 25 to $20 \%$ and endometritis from 34 to $29 \%$ compared with cows that did not receive the injectable trace minerals (Machado et al., 2013). Additionally, cows without trace mineral injection had lower SOD serum activity $(12.7 \mathrm{U} / \mathrm{mL})$ than cows administered injectable trace minerals (16.0 $\mathrm{U} / \mathrm{mL}$; Machado et al., 2014). Therefore, administration of injectable trace minerals allows for consistent trace mineral status while aiding the antioxidant response during stressful conditions (Teixeira et al., 2014).

Although it is known that trace minerals play a vital role in the immune system during oxidative stress, limited research exists regarding the relationship between trace mineral supplementation and AF exposure in dairy cows (Sordillo, 2013). Therefore, the objective of our study was to evaluate the effects of 2 subcutaneous injections of $15 \mathrm{mg} / \mathrm{mL}$ of $\mathrm{Cu}, 5 \mathrm{mg} / \mathrm{mL}$ of Se, 60 $\mathrm{mg} / \mathrm{mL}$ of $\mathrm{Zn}$, and $10 \mathrm{mg} / \mathrm{mL}$ of $\mathrm{Mn}$ (Multimin 90, Multimin North America, Fort Collins, CO) given at $1 \mathrm{~mL} / 90.7 \mathrm{~kg}$ of average BW on lactating multiparous Holstein cow performance, blood chemistry, liver mineral concentration, and liver inflammatory markers during an aflatoxin challenge.

\section{MATERIALS AND METHODS}

\section{Animal Care and Housing}

All experimental procedures were approved by the University of Illinois (Urbana-Champaign) Institutional Animal Care and Use Committee (\#16139). The experimental period occurred from November 2016
Table 1. Ingredient composition of the lactation diet fed to cows with negative control with no mineral injection (NEG), positive control with no mineral injection (POS), and treatment with mineral injection of Multimin 90 (MM) throughout the study

\begin{tabular}{|c|c|}
\hline Ingredient & $\%$ of DM \\
\hline Corn silage $^{1}$ & 36.37 \\
\hline Canola meal & 11.71 \\
\hline Alfalfa hay & 11.20 \\
\hline Corn gluten feed & 8.29 \\
\hline Soy hulls & 4.29 \\
\hline Wheat straw & 2.34 \\
\hline Dry ground corn grain & 19.25 \\
\hline Blood meal & 1.89 \\
\hline Rumen-protected lysine $^{2}$ & 0.62 \\
\hline Rumen-protected methionine ${ }^{3}$ & 0.15 \\
\hline Potassium carbonate & 0.13 \\
\hline Sodium bicarbonate & 1.31 \\
\hline Calcium & 1.08 \\
\hline Potassium chloride & 0.44 \\
\hline Urea $46 \%$ & 0.33 \\
\hline Salt, white & 0.20 \\
\hline Magnesium oxide $54 \%$ & 0.19 \\
\hline Vitamin and mineral mix ${ }^{4}$ & 0.22 \\
\hline
\end{tabular}

${ }^{1}$ All treatments fed at $34.2 \%$ corn silage DM.

${ }^{2}$ Ajipro-L Generation 2 (Ajinomoto Heartland Inc., Chicago, IL).

${ }^{3}$ Smartamine M (Adisseo, Alpharetta, GA).

${ }^{4}$ Vitamin and mineral mix was formulated to contain $12.51 \% \mathrm{Ca}$, $14.06 \% \mathrm{Na}, 9.60 \% \mathrm{Cl}, 3.18 \% \mathrm{Mg}, 6.48 \% \mathrm{~K}, 0.19 \% \mathrm{~S}, 26.93 \mathrm{mg} / \mathrm{kg}$ of $\mathrm{Co}, 301.01 \mathrm{mg} / \mathrm{kg}$ of $\mathrm{Cu}, 40.22 \mathrm{mg} / \mathrm{kg}$ of I, $678.25 \mathrm{mg} / \mathrm{kg}$ of $\mathrm{Fe}$, $1,519.35 \mathrm{mg} / \mathrm{kg}$ of Mn, $8.62 \mathrm{mg} / \mathrm{kg}$ of Se, $4.47 \mathrm{mg} / \mathrm{kg}$ of organic Se, $1621.05 \mathrm{mg} / \mathrm{kg}$ of $\mathrm{Zn}, 43.34 \mathrm{kIU} / \mathrm{kg}$ of vitamin $\mathrm{A}, 10.89 \mathrm{kIU} / \mathrm{kg}$ of vitamin $\mathrm{D}_{3}, 466.41 \mathrm{IU} / \mathrm{kg}$ of vitamin $\mathrm{E}, 4.23 \mathrm{mg} / \mathrm{kg}$ of biotin, 46.65 $\mathrm{mg} / \mathrm{kg}$ of thiamine, and $0.35 \mathrm{~g} / \mathrm{kg}$ of monensin (Rumensin, Elanco, Greenfield, IN).

to March 2017. Cows were fed ad libitum for a $5 \%$ minimum refusal and had constant access to water. Diet (TMR) was formulated according to NRC (2001) recommendations (Table 1) based on cows at 180 DIM, $703 \mathrm{~kg}$ of BW, producing $32 \mathrm{~kg}$ of milk/d with a target of $3.8 \%$ milk fat and $3.3 \%$ milk protein, and a predicted DMI of $25 \mathrm{~kg} / \mathrm{d}$.

\section{Experimental Design and Aflatoxin Challenge Procedure}

A total of 58 multiparous Holstein cows [BW (mean $\pm \mathrm{SD})=734 \pm 60 \mathrm{~kg} ; \mathrm{DIM}=191 \pm 93]$ were assigned to 1 of 3 treatments in a randomized complete block design consisting of 19 blocks. Cows were distributed into blocks with regard to lactation number, DIM, previous lactation 305-d milk yield, and BCS. Experimental period $(63 \mathrm{~d})$ was divided in an adaptation phase (d 1-56) and a measurement phase (d 57-63). From d 57 to 59 , cows received an AF challenge directly after feeding at $0700 \mathrm{~h}$. The AF challenge was similar to the one proposed by Kutz et al. (2009). Dietary AF was obtained from the Veterinary Medical Diagnostic Laboratory, College Veterinary Medicine, University of Missouri, Columbia, and consisted of Aspergillus 
parasiticus (NRRL-2999) culture material containing $102 \mathrm{mg} / \mathrm{kg}$ of $\mathrm{AFB}_{1}, 3.5 \mathrm{mg} / \mathrm{kg}$ of $\mathrm{AFB}_{2}, 35 \mathrm{mg} / \mathrm{kg}$ of $\mathrm{AFG}_{1}$, and $0.9 \mathrm{mg} / \mathrm{kg}$ of $\mathrm{AFG}_{2}$. The challenge consisted of $100 \mu \mathrm{g}$ of $\mathrm{AFB}_{1} / \mathrm{kg}$ of dietary DMI via $28-\mathrm{mL}$ gelatin capsules (Structure Probe Inc., West Chester, PA), administered orally via balling gun based on the average DMI obtained on d 54 to 56 . Treatments were: saline injection and no AF challenge (NEG), saline injection and $\mathrm{AF}$ challenge (POS), and trace mineral injection $[15 \mathrm{mg} / \mathrm{mL}$ of $\mathrm{Cu}, 5 \mathrm{mg} / \mathrm{mL}$ of $\mathrm{Se}, 60 \mathrm{mg} / \mathrm{mL}$ of $\mathrm{Zn}$, and $10 \mathrm{mg} / \mathrm{mL}$ of $\mathrm{Mn}$ (Multimin 90, Multimin North America)] and AF challenge (MM). All mineral treatments were administered according to the manufacturer's recommendation (http://www.multiminusa .com/products). Cows in NEG and POS received sterile saline (0.9\% Sodium Chloride Injection, USP, Hospira Inc., Lake Forest, IL) injections as a placebo. Mineral $(15 \mathrm{mg} / \mathrm{mL}$ of $\mathrm{Cu}, 5 \mathrm{mg} / \mathrm{mL}$ of $\mathrm{Se}, 60 \mathrm{mg} / \mathrm{mL}$ of $\mathrm{Zn}$, and $10 \mathrm{mg} / \mathrm{mL}$ of $\mathrm{Mn}$ ) and saline injections were performed subcutaneously directly after feeding at $0700 \mathrm{~h}$ on $\mathrm{d} 1$ and 29 at $1 \mathrm{~mL} / 90.7 \mathrm{~kg}$ of BW based on average BW from $\mathrm{d}-3$ to -1 and 26 to 28 relative to the start of the experiment, respectively. All cows were fed the same TMR throughout the trial once daily at $0700 \mathrm{~h}$.

\section{Data Collection and Sampling Procedures}

Samples of TMR (Tables 1 and 2) were obtained weekly and analyzed for DM (AOAC International, 1995a) by drying for $24 \mathrm{~h}$ in a forced-air oven at $110^{\circ} \mathrm{C}$. Diet composition was adjusted weekly for changes in DM content of ingredients. The TMR offered and refused from each cow was recorded to determine intake based on weekly DM analyses. Total mixed ration samples were taken weekly during the experimental period and stored at $-20^{\circ} \mathrm{C}$ until analyzed. Total mixed ration samples were composited every $3 \mathrm{wk}$ and TMR samples $(\mathrm{n}=3)$ were analyzed for contents of $\mathrm{DM}, \mathrm{CP}, \mathrm{ADF}$, $\mathrm{NDF}$, lignin, NFC, starch, fat, ash, TDN, Ca, P, Mg, K, $\mathrm{Na}, \mathrm{Fe}, \mathrm{Zn}, \mathrm{Cu}, \mathrm{Mn}, \mathrm{Mo}, \mathrm{S}$, and Se using wet chemistry methods (Dairy One, Ithaca, NY; Table 2). Values for TDN and $\mathrm{NE}_{\mathrm{L}}$ were provided by the laboratory and calculated based on NRC (2001). Additionally, 3 TMR samples $(\mathrm{n}=3)$ were stored at $-20^{\circ} \mathrm{C}$ until being sent to the Veterinary Medical Diagnostic Laboratory, College Veterinary Medicine, University of Missouri, Columbia, to be analyzed for AF concentrations. The physical characteristic of the TMR, based on the Penn State particle separator (Kononoff et al., 2003), was performed weekly.

Cows were milked 3 times daily at 0600, 1300, and 2200 h. Milk weights were recorded at every milking and samples were obtained at each milking on d 56 (adaptation phase) and from d 57 to 63 of the mea- surement phase. A preservative (800 Broad Spectrum Microtabs II; D\&F Control Systems Inc., San Ramon, CA) was added to the samples taken on d 57 and 59, and preserved samples were stored in a refrigerator at $8^{\circ} \mathrm{C}$, composited in proportion to milk yield, and sent to a commercial laboratory (Dairy Lab Services, Dubuque, IA) to be analyzed for contents of fat, true protein, MUN, lactose, TS, and SCC using mid-infrared procedures (AOAC International, 1995b; Table 3). In addition, the appearance and disappearance of $\mathrm{AFM}_{1}$ in milk was tested at each milking during the measurement phase with the use of a SNAP AFM $\mathrm{Am}_{1}$ test (Idexx, Westbrook, ME; detection level of $0.5 \mu \mathrm{g}$ of $\mathrm{AFM}_{1} /$ $\mathrm{kg}$ of milk). Milk samples on d 56,60, and 63 were stored at $-20^{\circ} \mathrm{C}$ until they were composited by day and sent to the Veterinary Medical Diagnostic Laboratory, College Veterinary Medicine, University of Missouri, Columbia, to be analyzed for $\mathrm{AFM}_{1}$ and $\mathrm{AFB}_{1}$ concentrations by HPLC with fluorescence detection methods as described in depth by Kutz et al. (2009; Table 3).

Blood was sampled from the coccygeal vein or artery at $0730 \mathrm{~h}$ on $\mathrm{d} 0,56,60$, and $63(\mathrm{n}=4)$ of the experimental period from each cow (BD Vacutainer; BD and Co., Franklin Lakes, NJ). Serum and plasma samples were obtained by centrifugation of the tubes at $2,500 \times g$ for $15 \mathrm{~min}$ at $4^{\circ} \mathrm{C}$ and stored at $-80^{\circ} \mathrm{C}$

Table 2. Mean chemical composition and associated SD for diets fed to cows with negative control with no mineral injection (NEG), positive control with no mineral injection (POS), and treatment with mineral injection of Multimin 90 (MM; Multimin North America, Fort Collins, CO) throughout the study

\begin{tabular}{lcc}
\hline Item & Mean $^{1}$ & $\mathrm{SD}^{2}$ \\
\hline DM, \% & 46.6 & 1.24 \\
CP, \% of DM & 17.5 & 0.39 \\
ADF, \% of DM & 18.4 & 1.29 \\
NDF, \% of DM & 30.6 & 1.16 \\
Lignin, \% of DM & 3.5 & 0.21 \\
NFC, \% of DM & 38.1 & 1.76 \\
Starch, \% of DM & 29.1 & 1.93 \\
Crude fat, \% of DM & 3.9 & 0.73 \\
Ash, \% of DM & 9.96 & 0.10 \\
TDN, \% of DM & 69.3 & 1.25 \\
NE, 3 Mcal/kg of DM & 1.62 & 0.03 \\
Ca, \% of DM & 1.45 & 0.29 \\
P, \% of DM & 0.48 & 0.01 \\
Mg, \% of DM & 0.34 & 0.02 \\
K, \% of DM & 1.52 & 0.05 \\
Na, \% of DM & 0.28 & 0.03 \\
S, \% of DM & 0.31 & 0.01 \\
Fe, mg/kg & 468.7 & 44.91 \\
Zn, mg/kg & 97.3 & 6.94 \\
Cu, mg/kg & 18.00 & 0.82 \\
Mn, mg/kg & 99.0 & 7.35 \\
Mo, mg/kg & 0.70 & 0.08 \\
Se, mg/kg & 0.54 & 0.02 \\
\hline Mean dit cmosition of & & \\
\hline
\end{tabular}

${ }^{1}$ Mean diet composition of 3 TMR samples $(n=3)$.

${ }^{2}$ Maximum SD between all samples.

${ }^{3} \mathrm{NRC}(2001)$. 
Table 3. Least squares means and associated SEM during the measurement phase for BW, BCS, production parameters response, and aflatoxin concentrations found in milk of Holstein cows in negative control with no mineral injection (NEG), positive control with no mineral injection (POS), and treatment with mineral injection of Multimin 90 (MM; Multimin North America, Fort Collins, CO)

\begin{tabular}{|c|c|c|c|c|c|c|}
\hline \multirow[b]{2}{*}{ Variable } & \multicolumn{3}{|c|}{ Treatment $^{1}$} & \multirow[b]{2}{*}{ SEM } & \multicolumn{2}{|c|}{$\begin{array}{c}\text { Contrasts, }^{2} \\
P \text {-value }\end{array}$} \\
\hline & NEG & POS & MM & & 1 & 2 \\
\hline DMI, $\mathrm{kg} / \mathrm{d}$ & 23.00 & 24.91 & 23.42 & 1.00 & 0.16 & 0.33 \\
\hline $\mathrm{BW}, \mathrm{kg}$ & 734 & 772 & 736 & 16.83 & 0.12 & 0.14 \\
\hline DMI, $\%$ of BW & 3.14 & 3.26 & 3.22 & 0.17 & 0.62 & 0.87 \\
\hline BCS & 3.39 & 3.61 & 3.52 & 0.06 & 0.02 & 0.34 \\
\hline \multicolumn{7}{|l|}{ Milk yield } \\
\hline Milk yield, kg/d & 32.57 & 29.85 & 30.60 & 1.50 & 0.20 & 0.73 \\
\hline $3.5 \%$ FCM, $\mathrm{kg} / \mathrm{d}$ & 32.09 & 28.63 & 27.95 & 1.47 & 0.09 & 0.75 \\
\hline ECM, kg/d & 32.84 & 29.18 & 30.26 & 1.63 & 0.11 & 0.64 \\
\hline $\mathrm{AFM}_{1} \mathrm{Snap}^{3}$ & 0.0 & 12.8 & 12.4 & 0.32 & $<0.001$ & 0.40 \\
\hline Milk discarded, ${ }^{4} \mathrm{~kg}$ & 0.00 & 129.0 & 128.3 & 9.55 & $<0.001$ & 0.96 \\
\hline \multicolumn{7}{|l|}{ Milk composition } \\
\hline Fat, $\%$ & 3.51 & 3.31 & 3.33 & 0.17 & 0.41 & 0.92 \\
\hline Fat, kg/d & 1.11 & 0.96 & 0.99 & 0.07 & 0.14 & 0.76 \\
\hline Protein, \% & 3.53 & 3.43 & 3.51 & 0.05 & 0.17 & 0.32 \\
\hline Protein, $\mathrm{kg} / \mathrm{d}$ & 1.13 & 1.01 & 1.07 & 0.05 & 0.10 & 0.42 \\
\hline Lactose, \% & 4.56 & 4.59 & 4.52 & 0.07 & 0.72 & 0.50 \\
\hline Lactose, $\mathrm{kg} / \mathrm{d}$ & 1.50 & 1.38 & 1.42 & 0.07 & 0.25 & 0.71 \\
\hline MUN, mg/dL & 13.37 & 14.30 & 13.27 & 0.33 & 0.05 & 0.03 \\
\hline $\mathrm{SCC}, \times 1,000 / \mathrm{mL}$ & 4.29 & 4.23 & 4.54 & 0.34 & 0.91 & 0.53 \\
\hline $3.5 \%$ FCM/DMI & 1.42 & 1.16 & 1.26 & 0.08 & 0.02 & 0.37 \\
\hline ECM/DMI & 1.46 & 1.18 & 1.29 & 0.07 & 0.01 & 0.31 \\
\hline Milk/DMI & 1.45 & 1.22 & 1.30 & 0.07 & 0.02 & 0.39 \\
\hline Milk $\mathrm{AFM}_{1},{ }^{5} \mu \mathrm{g} / \mathrm{kg}$ & 0.00 & 0.18 & 0.18 & 0.01 & $<0.001$ & 0.90 \\
\hline Milk $\mathrm{AFM}_{1} \mathrm{~d} 60,{ }^{6} \mu \mathrm{g} / \mathrm{kg}$ & 0.00 & 0.50 & 0.50 & 0.03 & $<0.001$ & 0.92 \\
\hline AFM excretion, ${ }^{7} \mu \mathrm{g} / \mathrm{d}$ & 0.00 & 16.71 & 15.75 & 1.82 & $<0.001$ & 0.66 \\
\hline AFM transfer, ${ }^{8} \%$ & 0.00 & 0.61 & 0.64 & 0.06 & $<0.001$ & 0.74 \\
\hline
\end{tabular}

${ }^{1}$ Aflatoxin (AF) challenge: $100 \mu \mathrm{g}$ of $\mathrm{AF} / \mathrm{kg}$ of DMI of spiked corn, based on average DMI of the last $3 \mathrm{~d}$ before the challenge.

${ }^{2}$ Contrasts were 1 = NEG compared with POS; 2 = POS compared with MM.

${ }^{3}$ Number of milkings with a positive snap test.

${ }^{4}$ Total amount of milk discarded per cow during the measurement phase.

${ }^{5}$ Samples that were analyzed were collected on $\mathrm{d} 56,60$, and 63 . Treatment $\times$ day interaction was present $(P$ $<0.0001$; Figure 1).

${ }^{6}$ Samples that were analyzed were collected on d 60 .

${ }^{7} \mathrm{AFM}$ excretion $=\mathrm{AFM}_{1}(\mu \mathrm{g})$ concentration in milk on $\mathrm{d} 60 \times$ milk yield on $\mathrm{d} 60(\mathrm{~kg})$. Calculations were done solely on d 60 to demonstrate the effectiveness at the highest concentration of $\mathrm{AFM}_{1}$. NEG $=33.97$, POS $=$ $30.54 \mathrm{~kg}, \mathrm{MM}=31.21, \mathrm{SEM}=10.50$.

${ }^{8} \mathrm{AFM}$ transfer $=($ AFM excretion, $\mu \mathrm{g} / \mathrm{d} / \mathrm{AFM}$ intake, $\mu \mathrm{g} / \mathrm{d}) \times 100$.

for further analysis. Beta-hydroxybutyrate was analyzed from whole blood immediately after sampling using a digital cow-side ketone monitor (Nova Max Plus, Nova Biomedical Corporation, Waltham, MA). Heparinized plasma samples were sent to the University of Illinois Veterinary Diagnostic Laboratory to be analyzed for bovine chemistry profiles (BUN, albumin, and alkaline phosphatase) using the AU680 Beckman Coulter Chemistry Analyzer (Beckman Coulter Inc., Atlanta, GA; http://vetmed.illinois.edu/vet-resources/ veterinary-diagnostic-laboratory/clinical-pathology/). Commercially available kits were used to analyze heparinized plasma samples for glucose, SOD activity, GSHPx activity, and serum amyloid A. Plasma glucose was assessed using the Glucose Autokit Assay (Wako Pure
Chemical Industries Ltd., Mountain View, CA). Serum cholesterol was assessed using the Cholesterol E assay (Wako Pure Chemical Industries Ltd.). Plasma SOD activity was assessed using Superoxidase Dismutase Assay kit, in which the dismutation of superoxide radicals generated by xanthine oxidase and hypoxanthine were measured (Cayman Chemical, Ann Arbor, MI), and plasma GSH-Px activity was measured using the Glutathione Peroxidase Assay kit with an indirect enzymatic recycling method, using glutathione reductase for the quantification of glutathione reduction by GSHPx (Cayman Chemical); both were completed following manufacturer's instructions (https://www.caymanchem .com/product/706002 and https://www.caymanchem .com/product/703102). Serum amyloid A was assessed 
Table 4. Least squares means and associated SEM for mineral concentrations found in liver and blood metabolites of Holstein cows in negative control with no mineral injection (NEG), positive control with no mineral injection (POS), and treatment with mineral injection of Multimin 90 (MM; Multimin North America, Fort Collins, CO)

\begin{tabular}{|c|c|c|c|c|c|c|}
\hline \multirow[b]{2}{*}{ Variable } & \multicolumn{3}{|c|}{ Treatment $^{1}$} & \multirow[b]{2}{*}{ SEM } & \multicolumn{2}{|c|}{$\begin{array}{c}\text { Contrasts, }{ }^{2} \\
P \text {-value }\end{array}$} \\
\hline & NEG & POS & MM & & 1 & 2 \\
\hline \multicolumn{7}{|l|}{ Liver, ${ }^{3} \mu \mathrm{g} / \mathrm{g}$ of $\mathrm{DM}$} \\
\hline Arsenic & 0.12 & 0.12 & 0.12 & 0.003 & 0.74 & 0.43 \\
\hline Cadmium & 0.13 & 0.12 & 0.12 & 0.005 & 0.14 & 0.61 \\
\hline Cobalt & 0.41 & 0.42 & 0.42 & 0.02 & 0.86 & 0.87 \\
\hline Copper & 635 & 609 & 651 & 24.20 & 0.42 & 0.20 \\
\hline Iron & 201.6 & 190.8 & 214.4 & 7.76 & 0.27 & 0.02 \\
\hline Lead & 0.12 & 0.12 & 0.12 & 0.004 & 0.74 & 0.65 \\
\hline Manganese & 11.53 & 12.33 & 11.64 & 0.38 & 0.12 & 0.18 \\
\hline Mercury & 0.58 & 0.59 & 0.60 & 0.02 & 0.95 & 0.61 \\
\hline Molybdenum & 3.79 & 3.83 & 3.84 & 0.11 & 0.79 & 0.99 \\
\hline Selenium & 3.86 & 4.00 & 4.56 & 0.20 & 0.60 & 0.04 \\
\hline Thallium & 0.12 & 0.12 & 0.11 & 0.003 & 0.74 & 0.43 \\
\hline Zinc & 102.7 & 108.7 & 110.9 & 5.30 & 0.43 & 0.73 \\
\hline \multicolumn{7}{|l|}{ Blood $^{4}$} \\
\hline BUN, mg/dL & 16.43 & 16.55 & 15.79 & 0.26 & 0.76 & 0.04 \\
\hline Alkaline phosphatase, U/L & 39.5 & 36.4 & 44.1 & 1.76 & 0.19 & $<0.001$ \\
\hline $\mathrm{BHB}, \mathrm{mg} / \mathrm{dL}$ & 0.51 & 0.53 & 0.50 & 0.03 & 0.59 & 0.44 \\
\hline Albumin, g/dL & 3.48 & 3.57 & 3.45 & 0.03 & 0.09 & 0.01 \\
\hline Glucose, $\mathrm{mg} / \mathrm{dL}$ & 55.2 & 54.1 & 58.3 & 2.16 & 0.73 & 0.17 \\
\hline Cholesterol, mg/dL & 150.6 & 158.7 & 170.6 & 9.72 & 0.53 & 0.36 \\
\hline $\mathrm{SOD},{ }^{5} \mathrm{U} / \mathrm{mL}$ & 2.50 & 2.52 & 2.41 & 0.12 & 0.92 & 0.48 \\
\hline GSH-Px,${ }^{6} \mathrm{nmol} / \mathrm{min}$ per $\mathrm{mL}$ & 24.9 & 24.2 & 30.2 & 2.48 & 0.86 & 0.10 \\
\hline Serum amyloid $\mathrm{A}, \mu \mathrm{g} / \mathrm{mL}$ & 147 & 136 & 180 & 25.81 & 0.86 & 0.87 \\
\hline
\end{tabular}

${ }^{1}$ Aflatoxin (AF) challenge: $100 \mu \mathrm{g}$ of $\mathrm{AF} / \mathrm{kg}$ of DMI of spiked corn, based on average DMI of the last $3 \mathrm{~d}$ before the challenge.

${ }^{2}$ Contrasts were 1 = NEG compared with POS; 2 = POS compared with MM. Day differed for BUN, alkaline phosphatase, albumin, cholesterol, SOD, and GSH-Px $(P<0.05)$. Treatment differed for albumin and alkaline phosphatase $(P<0.05)$. Treatment $\times$ day interaction was not present $(P>0.08)$ for all variables.

${ }^{3}$ Liver samples analyzed were collected on $\mathrm{d} 0$ and 60 . Day 0 was used as a covariate, whereas d 60 was analyzed to demonstrate the effectiveness at the highest concentration of AFM excretion.

${ }^{4}$ All samples were run on blood plasma except cholesterol (blood serum).

${ }^{5}$ Super oxide dismutase. One unit is defined as the amount of enzyme needed to exhibit $50 \%$ dismutation of the superoxide radical.

${ }^{6}$ Glutathione peroxidase activity. One unit $(\mathrm{nmol} / \mathrm{min})$ is defined as the amount of enzyme that will cause the oxidation of $1.0 \mathrm{nmol}$ of $\mathrm{NADPH}$ to $\mathrm{NADP}^{+}$per minute at $25^{\circ} \mathrm{C}$.

using the phase Range Multispecies serum amyloid A ELISA kit (Tridelta Development, Ltd., Maynooth, Ireland) following manufacturer's instructions (http:// www.trideltaltd.com/Serum-Amyloid-A-Assay-Kit .html).

Liver biopsies were conducted on d 0 and 60 from each cow using a similar technique described by Vailati Riboni et al. (2015). An 18-gauge by 10.2-cm bone marrow probe (Monoject-8881247087, Medtronic, Fridley, MN), was used to obtain approximately $2 \mathrm{~g}$ (wet weight) of liver sample. Liver samples were snap-frozen and stored in liquid nitrogen. Samples for each cow for each day were sent to Michigan State University Diagnostic Center for Population and Animal Health (Lansing) to be analyzed for $\mathrm{As}, \mathrm{Cd}, \mathrm{Co}, \mathrm{Cu}, \mathrm{Fe}, \mathrm{Pb}$, Mn, Hg, Mb, Se, Tl, and Zn (Table 4).
Health evaluations were performed daily during the measurement phase. Visual assessments were performed to monitor general appearance and fecal score. Rectal temperature was measured using a GLA M700 Thermometer (GLA Agricultural Electronics, San Luis Obispo, CA). Respiration rate was recorded by visual observation for $15 \mathrm{~s}$, and heart rate was measured via palpation of the femoral artery for $15 \mathrm{~s}$. General appearance was scored using a similar method to Krause et al. (2009), where $4=$ bright and alert; $3=$ depressed; $2=$ reluctant to rise; and $1=$ down cow, will not get up. Fecal scores were allocated on a 1 to 4 scale according to Krause et al. (2009), where 1 = runny: liquid consistency, splatters on impact, spreads readily; $2=$ loose: may pile slightly and spreads and splatters moderately on impact and setting; 3 = soft: piles up but spreads 
slightly on impact and settling; and $4=$ dry: hard, dry appearance, original form not distorted on impact and settling. Body temperature was considered elevated if $>39.4^{\circ} \mathrm{C}$, heart rate was considered elevated if $>100$ beats/min, respiratory rate was considered abnormal if $>40$ breaths/min, general appearance was considered abnormal if $\leq 2$, and fecal score was considered abnormal if $\leq 2$ (Ireland-Perry and Stallings, 1993; Krause and Oetzel, 2005). Body weight was measured (Ohaus digital scale, model CW-11, Newark, NJ) and BCS was assigned in quarter-unit increments for each cow weekly (Ferguson et al., 1994). More than 1 person assigned a BCS score independently at each time of scoring and the average score was used for statistical analysis.

\section{Hepatic Gene Expression}

Complete details of the procedures are included in the Supplemental Material (https://doi.org/10.3168/ jds.2018-14447). Briefly, total RNA was extracted and used for cDNA synthesis. Real-time quantitative PCR preformed was SYBR Green-based (PerfeCTa SYBR Green FastMix ROX, Quanta Biosciences Inc., Gaithersburg, MD) using a 6-point standard curve. The extraction and quantitative PCR analysis were preformed using previously established protocols at Juan Loor's (University of Illinois) laboratory (Vailati Riboni et al., 2015). Eleven genes were selected for transcript profiling in liver tissue, namely albumin $(A L B)$, ceruloplasmin $(C P)$, cytochrome P450-1A2 (CYP1A2), glutamate dehydrogenase (GLUD1), glutathione peroxidase (GPX1), haptoglobin $(H P)$, malate dehydrogenase (MDH2), nuclear factor kappa B (NFKB1), superoxide dismutase (SOD2), signal transducer and activator of transcription (STAT5A), and tumor necrosis factor $\alpha(T N F A)$. All primers were designed for the current experiment (Integrated DNA Technologies, Coralville, IA). The final data were normalized using the geometric mean of 3 internal control genes: GAPDH, RPS9, and UXT (Khan et al., 2015).

\section{Aflatoxin Calculations}

Aflatoxin $\mathrm{M}_{1}$ excretion $(\mu \mathrm{g} / \mathrm{kg})$ was calculated in comparison to Maki et al. (2016). Excretion $(\mu \mathrm{g} / \mathrm{kg})$ was calculated as the concentration of $\mathrm{AFM}_{1}$ in milk on d $60(\mu \mathrm{g})$ multiplied by milk yield on d $60(\mathrm{~kg})$; AF transfer $(\mathrm{g} / \mathrm{kg})$ was calculated as [AF excretion $(\mu \mathrm{g} /$ $\mathrm{kg}) / \mathrm{AFB}_{1}$ challenge $\left.(\mu \mathrm{g} / \mathrm{kg})\right] \times 100$.

\section{Statistical Analyses}

Data collected from d 57 to 63 were analyzed using SAS (v. 9.4, SAS Institute Inc., Cary NC). For produc- tion variables, liver mineral concentration, and gene expression, the MIXED procedure of SAS was used to model the fixed effects of treatment and block as

$$
Y_{i j}=\mu+T_{i}+B_{j}+\varepsilon_{i j},
$$

where $Y_{i j}=$ the observations for dependent variables; $\mu=$ the overall mean; $T_{i}=$ the fixed effect of the $i$ th treatment; $B_{j}=$ effect of the $j$ th block; and $\varepsilon_{i j}=$ the random residual error. Covariate (d 0) was included for blood metabolite variables, liver mineral variables, and gene expression. For variables with measurement over time, the MIXED procedure of SAS was used to model the fixed effects of treatment, day, and block using the model

$$
Y_{i j k}=\mu+T_{i}+D_{j}+T_{i} \times D_{j}+B_{k}+\varepsilon_{i j k},
$$

where $Y_{i j k}=$ the observations for dependent variables; $\mu=$ the overall mean; $T_{i}=$ the fixed effect of the $i$ th treatment; $D_{j}=$ the repeated measurement (day) effect; $T_{i} \times D_{j}=$ the interaction of treatment and repeated measurement; $B_{k}=$ effect of the $k$ th block; and $\varepsilon_{i j k}$ $=$ the random residual error. The estimation method was restrictive maximum likelihood (REML) and the degrees of freedom method was Kenward-Rogers (Littell , 2002). Variables were subjected to 5 covariance structures: compound symmetry, autoregressive order 1 , autoregressive heterogeneous order 1, unstructured, and Toeplitz. The covariance structure that yielded the lowest corrected Akaike information criterion was compound symmetry and used in the model (Littell, 2002). For both models, cow was the experimental unit and considered as a random effect.

Somatic cell count was log-transformed for better normality and homoscedasticity of residuals. Data presented for this variable was back-transformed. Two treatment orthogonal contrasts were used. Contrast 1 (CONT1) was the negative control treatment (saline injection and no AF challenge) compared with the positive control treatment (saline injection $+\mathrm{AF}$ challenge). Contrast 2 (CONT2) was the positive control treatment (saline injection + AF challenge) compared with the mineral injection treatment cows (mineral injection + AF challenge). Residuals distribution was evaluated for normality and homoscedasticity.

Cows that developed mastitis $(\mathrm{n}=2$, POS; $\mathrm{n}=1$, $\mathrm{CON} ; \mathrm{n}=1, \mathrm{MM}$ ) during the measurement phase ( $\mathrm{d} 57$ to 63 ) were removed from the data set along with cows that had abnormally low milk production $(0.77 \pm 0.21$ $\mathrm{kg} / \mathrm{d}$ ) due to later stage of lactation (DIM $=419 \pm 3$ $\mathrm{d} ; \mathrm{n}=1, \mathrm{MM})$. Statistical significance was declared at $P \leq 0.05$ and trends at $0.05<P \leq 0.10$. 


\section{RESULTS}

\section{Diet Composition}

The ingredient composition of the diet is in Table 1. Analyzed nutrients from the experimental diet are in Table 2. The physical characteristics of the TMR, based on the Penn State particle separator (Kononoff et al., 2003), was (mean \pm SD) $2.6 \pm 1.0 \%$ on upper (19 $\mathrm{mm}$ pore size), $42.9 \pm 8.6 \%$ on middle $(8 \mathrm{~mm}$ pore size), and $15.0 \pm 0.5 \%$ on lower ( $4 \mathrm{~mm}$ pore size) sieves, and $39.5 \pm 10.0 \%$ in the pan.

\section{DMI, BW, BCS, and Lactation Performance}

Performance data from the measurement phase (d 57-63) are in Table 3. We found no treatment differences for either contrasts (CONT1 or CONT2) for DMI, milk yield, BW, or DMI as a percentage of BW. Body condition score was greater for cows in POS than cows in NEG $(P=0.02)$. Fat-corrected milk $(3.5 \%)$ tended to be greater for cows in NEG compared with cows in POS $(P=0.09)$. Cows in POS had decreased feed conversion compared with cows in NEG $(3.5 \% \mathrm{FCM} /$ DMI, $P=0.02 ; \mathrm{ECM} / \mathrm{DMI}, P=0.01$; and milk yield/ DMI, $P=0.02)$. Protein yield $(\mathrm{kg} / \mathrm{d})$, tended to be greater for cows in NEG compared with cows in POS $(P=0.10)$. Cows in POS had greater MUN concentrations than cows in both NEG and MM $(P=0.05$ and 0.03 , respectively). The number of milkings with positive SNAP $\mathrm{AFM}_{1}$ test (greater than $0.5 \mu \mathrm{g}$ of $\mathrm{AFM}_{1} /$ $\mathrm{kg}$ of milk) and total milk discarded (landfill due to regulations by the FDA on $\mathrm{AFM}_{1}$ concentrations) was greater for cows in POS than from cows in $\mathrm{CON}(P<$ 0.0001 and $P<0.0001$, respectively).

\section{AF Concentrations}

Aflatoxin concentrations in TMR were below detection limits (10 $\mu \mathrm{g}$ of $\mathrm{AF} / \mathrm{kg}$ of TMR). Aflatoxin concentrations in milk are in Table 3. Milk $\mathrm{AFM}_{1}$ concentrations during the measurement phase were lower $(P<$ $0.0001)$ for cows in NEG compared with cows in POS. Cows in CON had lower $(P<0.0001) \mathrm{AFM}_{1}$ concentrations at $\mathrm{d} 60$ than cows in POS. Cows in CON had lower $\mathrm{AFM}_{1}$ excretion and transference $(P<0.0001$ and $P$ $<0.0001$, respectively) during the measurement phase than cows in POS. A treatment effect and a day effect were observed for milk $\mathrm{AFM}_{1}$ concentration during the measurement phase $(P<0.0001$ and $P<0.0001$, respectively), as well as a treatment $\times$ day interaction $(P<0.0001 ;$ Figure 1).

\section{Serum and Plasma Chemistry Profile}

Serum and plasma chemistry profiles are in Table 4. Albumin $(\mathrm{g} / \mathrm{dL})$ was greater $(P=0.04)$ for cows in POS compared with those in MM, and tended to be greater $(P=0.09)$ for cows in POS compared with those in NEG. Blood urea nitrogen $(\mathrm{mg} / \mathrm{dL})$ was greater $(P=0.04)$ for cows in POS compared with those in MM. Cows in MM had greater plasma concentrations

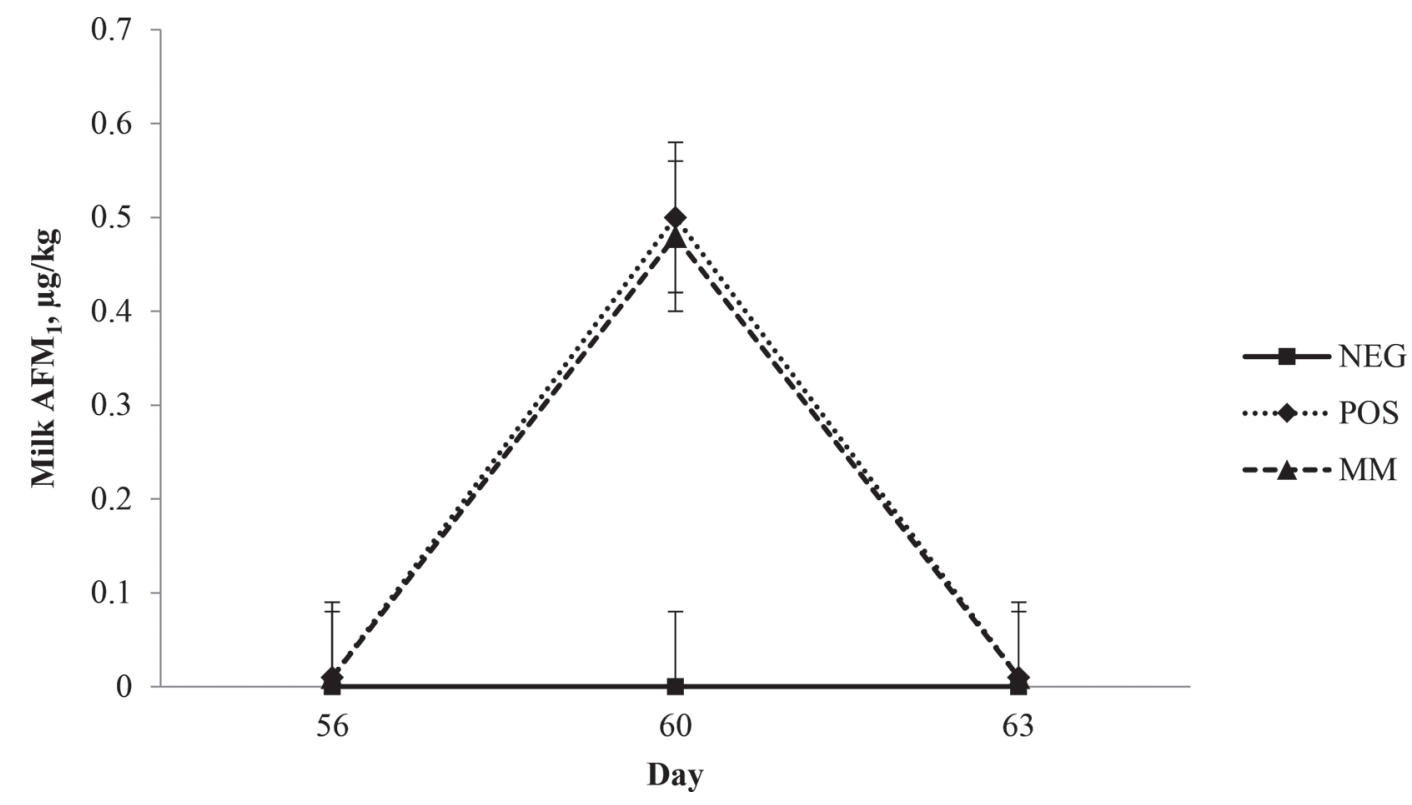

Figure 1. Least squares means and associated SEM for milk AFM excretion concentration response of Holstein cows in negative control with no mineral injection (NEG), positive control with no mineral injection (POS), and treatment with mineral injection of Multimin 90 (MM; Multimin North America, Fort Collins, CO). Samples were taken on d 56, 60, and 63 of the experimental period. Treatment $\times$ day: $P<0.0001$. 
Table 5. Accession number, gene symbol, and forward and reverse primer sequences ( $5^{\prime} 3^{\prime}$ used in real-time PCR) of genes analyzed in liver tissue

\begin{tabular}{llll}
\hline Accession no. & Symbol & Forward sequence & Reverse sequence \\
\hline BC151546.1 & ALB & AGTGCTGCACAGAGTCATTGGT & GGCTTTGGGTACATATGTTTCATCA \\
NM_001256556.1 & CP & GGTTGACACGGAACATTCCAA & GGCCTAAAAACCCTAACCAGACA \\
XM_010798596.2 & CYP1A2 & CAGTAAGGAGATGCTCAGTC & CTGTTCTTGTCAAAGTCTGG \\
NM_001034034.2 & GAPDH & TGGAAAGGCCATCACCATCT & CCCACTTGATGTTGGCAG \\
NM_182652.2 & GLUD1 & CGTTTTGGTGCTAAATGTATTGCT & CATGTTGCAATTTGAAGTCTTCCA \\
NM_174076.3 & GPX1 & GCAAGGTGCTGCTCATTGAG & CGCTGCAGGTCATTCATCTG \\
NM_001040470.2 & HP & GGTTCGGAAAACCATCGCTA & CACTCGTGTCCCCTCCCTC \\
NM_001013587.1 & MDH2 & TCTGCATCATCTCAAATCCAGTTAAC & GTCACCCCGAAGATTTTGTTG \\
NM_001076409.1 & NFKB1 & TTCAACCGGAGATGCCACTAC & ACACACGTAACGGAAACGAAATC \\
NM_001101152.2 & RPS9 & CCTCGACCAAGAGCTGAAG & CCTCCAGACCTCACGTTTGTTC \\
NM_201527.2 & SOD2 & CGCTGGAGAAGGGTGATGTT & GATTTGTCCAGAAGATGCTGTGAT \\
NM_001012673.1 & STAT5A & TCGCCACATTCTGTACAATGAAC & CTGGTTGATCTGAAGGTGTTTCTG \\
NM_173966.3 & TNFA & CCAGAGGGAAGAGCAGTCCC & TCGGCTACAACGTGGGCTAC \\
BC108205.1 & UXT & TGTGGCCCTTGGATATGGTT & GGTTGTCGCTGAGCTCTGTG \\
\hline
\end{tabular}

of alkaline phosphatase $(\mathrm{U} / \mathrm{L})$ than cows in POS $(P<$ 0.001). Cows in MM tended to have increased plasma GSH-Px activity (nmol/min/mL) compared with cows in $\operatorname{POS}(P=0.10)$.

\section{Liver Mineral Concentration}

Liver mineral concentration data are in Table 4. Cows receiving the mineral injection (MM) had greater liver concentrations of $\mathrm{Se}(\mu \mathrm{g} / \mathrm{g}$ of liver $\mathrm{DM})$ than cows in POS $(P=0.04)$. Cows in MM had greater liver concentrations of $\mathrm{Fe}(\mu \mathrm{g} / \mathrm{g}$ of liver $\mathrm{DM})$ compared with cows in POS $(P=0.02)$.

\section{Hepatic Gene Expression}

Accession numbers, gene symbols, as well as forward and reverse sequences for all primers are in Table 5 . Hepatic gene expression data are in Table 6; GPX1 expression was greater in liver of cows in POS than cows in NEG and MM $(P=0.005$ and $P=0.01$, respectively). Cows in POS tended $(P=0.08)$ to have greater NFKB1 expression in liver compared with cows in NEG.

\section{DISCUSSION}

The objective of our study was to evaluate the effects of 2 subcutaneous injections of $15 \mathrm{mg} / \mathrm{mL}$ of $\mathrm{Cu}, 5 \mathrm{mg} /$ $\mathrm{mL}$ of $\mathrm{Se}, 60 \mathrm{mg} / \mathrm{mL}$ of $\mathrm{Zn}$, and $10 \mathrm{mg} / \mathrm{mL}$ of $\mathrm{Mn}$ given at $1 \mathrm{~mL} / 90.7 \mathrm{~kg}$ of average BW to post-peak lactating multiparous Holstein cows on performance, blood chemistry, liver mineral concentration, and liver inflammatory markers during an aflatoxin challenge. Our hypothesis was that cows receiving mineral injection would experience lower oxidative stress due to an AF challenge than cows not receiving the mineral injection.
As in previous studies, decreased milk $\mathrm{AFM}_{1}$ excretion was expected in cows not receiving an AF compared with cows receiving an AF (Xiong et al., 2015; Sulzberger et al., 2017; Weatherly et al., 2018). This was supported in the present study, as cows without an AF challenge had no $\mathrm{AFM}_{1}$ excretion in milk, lower number of positive SNAP AFM 1 test (Idexx), and lower total milk discarded $(\mathrm{kg})$ due to AF contamination. Additionally, we observed no differences in milk $\mathrm{AFM}_{1}$ excretion between cows treated with or without trace mineral injection during an AF challenge. These results were anticipated, as trace mineral was injected subcutaneously, and did not sequester $\mathrm{AF}$ in the digestive

Table 6. Least squares means and associated SEM for liver gene expression response of Holstein cows in negative control with no mineral injection (NEG), positive control with no mineral injection (POS), and treatment with mineral injection of Multimin 90 (MM; Multimin North America, Fort Collins, CO)

\begin{tabular}{lcccccc}
\hline & \multicolumn{3}{c}{ Treatment $^{2}$} & & \multicolumn{2}{c}{$\begin{array}{c}\text { Contrasts, } \\
\text { P-value }\end{array}$} \\
\cline { 2 - 4 } \cline { 5 - 7 } Gene $^{1}$ & NEG & POS & MM & SEM & 1 & 2 \\
\hline ALB & 0.97 & 0.98 & 0.94 & 0.07 & 0.83 & 0.52 \\
CP & 0.91 & 1.00 & 1.09 & 0.14 & 0.45 & 0.53 \\
CYP1A2 & 1.05 & 1.09 & 1.13 & 0.09 & 0.59 & 0.72 \\
GLUD1 & 0.91 & 0.95 & 0.87 & 0.07 & 0.41 & 0.12 \\
GPX1 & 0.93 & 1.07 & 0.95 & 0.05 & 0.005 & 0.01 \\
HP & 0.04 & 0.07 & 0.13 & 0.93 & 0.46 & 0.47 \\
MDH2 & 1.00 & 1.00 & 0.99 & 0.06 & 0.98 & 0.88 \\
NFKB1 & 1.01 & 1.12 & 1.07 & 0.06 & 0.08 & 0.39 \\
SOD2 & 0.97 & 1.02 & 0.98 & 0.07 & 0.48 & 0.59 \\
STAT5A & 1.15 & 1.21 & 1.22 & 0.07 & 0.44 & 0.84 \\
TNFA & 0.93 & 1.00 & 0.90 & 0.14 & 0.61 & 0.43 \\
\hline
\end{tabular}

${ }^{1}$ Liver samples analyzed were collected on d 0 and 60. Day 0 was used as a covariate, whereas d 60 was analyzed to demonstrate the effectiveness at the highest concentration of AFM excretion.

${ }^{2}$ Aflatoxin (AF) challenge: $100 \mu \mathrm{g}$ of $\mathrm{AF} / \mathrm{kg}$ of DMI of spiked corn, based on average DMI of the last $3 \mathrm{~d}$ before the challenge.

${ }^{3}$ Contrasts were $1=$ NEG compared with POS; $2=$ POS compared with MM. 
tract. However, other AF-mitigation strategies, such as adsorbent treatment, are proven to sequester $\mathrm{AF}$ by limiting bioavailability through ion exchange (Moschini et al., 2008) and have shown decreased milk AF excretion (Xiong et al., 2015; Ogunade et al., 2016; Sulzberger et al., 2017). Therefore, trace mineral injection does not provide effective decrease in milk AF excretion during an AF challenge compared with an adsorbent mitigation strategy.

Xiong et al. (2015) reported no differences in DMI, milk yield, or feed efficiency for cows with or without an AF challenge. Similar results were present in the current study for DMI and milk yield; however, cows receiving an $\mathrm{AF}$ challenge without mineral injection had lower feed efficiencies (3.5\% FCM/DMI, ECM/ DMI, and milk/DMI) than cows without an AF challenge. Sulzberger et al. (2017) reported decreased feed efficiencies for cows challenged with an AF. These results indicate that an AF challenge negatively affects cow's metabolic efficiency in conversion of feed to milk.

In the current study, cows in POS had greater MUN and a tendency for lower protein yield $(\mathrm{kg} / \mathrm{d})$ than cows in NEG. Cows in POS also had greater MUN and BUN than cows in MM. The mechanism behind greater nitrogen concentrations in milk and blood during stress are not fully understood; however, it has been postulated that hepatocyte inflammation may cause increased protein degradation via deamination, forming $\mathrm{NH}_{4}{ }^{+}$as a by-product, and therefore lead to greater BUN and MUN (Pearce et al., 2015; Gao et al., 2017). Although not directly associated with stress caused by an AF challenge, research evaluating heat stress provides evidence to support this postulation regarding nitrogen metabolism. Gao et al. (2017) reported that heat-stressed cows had greater urinary urea nitrogen and MUN, and had a tendency for greater plasma urea nitrogen, than did cows under thermoneutral conditions. Milk protein percentage and protein yield were also decreased for heat-stressed cows (Gao et al., 2017). Similar results have been shown in pigs, with heatstressed pigs having greater concentrations of plasma urea nitrogen than nonheat-stressed pigs (Pearce et al., 2015). Additionally, liver gene expression data may be used to support the theory that liver inflammation alters nitrogen metabolism. The gene NFKB1 is considered to be antiapoptotic, and increased NFKB1 expression has been shown to upregulate other inflammatory genes, such as TNFA and IL6 (Baker et al., 2011; Shi et al., 2016). Previous work has demonstrated that AF exposure increases $N F K B 1$ expression in rats susceptible to hepatocellular carcinoma compared with resistant rats (Shi et al., 2016). In the current study, an upregulation in liver NFKB1 gene expression was present for cows in POS compared with cows in NEG. These results could indicate an increase in hepatic inflammation and, consequently, protein degradation and deamination during an AF challenge, which may be contributing to greater nitrogen concentrations in blood and milk.

Previous research showed that a subcutaneous injection of $15 \mathrm{mg} / \mathrm{mL}$ of $\mathrm{Cu}, 5 \mathrm{mg} / \mathrm{mL}$ of $\mathrm{Se}, 60 \mathrm{mg} / \mathrm{mL}$ of $\mathrm{Zn}$, and $10 \mathrm{mg} / \mathrm{mL}$ of $\mathrm{Mn}$ given at $1 \mathrm{~mL} / 68 \mathrm{~kg}$ of $\mathrm{BW}$ resulted in greater concentrations of liver $\mathrm{Cu}$ and $\mathrm{Se}$, with no difference in $\mathrm{Zn}$ or $\mathrm{Mn}$ in feedlot cattle (Genther and Hansen, 2014). Similarly, in the current study, cows in MM had greater concentrations of liver Se compared with cows in POS. The liver represents the storage pool for $\mathrm{Se}$ and $\mathrm{Cu}$, but liver concentrations of $\mathrm{Zn}$ and $\mathrm{Mn}$ do not properly reflect mineral status in dairy cattle (Herdt and Hoff, 2011). This could explain why no differences in liver $\mathrm{Zn}$ or Mn concentrations were seen when cows received trace mineral injection. Likewise, trace mineral injection occurred on d 29 of the experimental period, $31 \mathrm{~d}$ before liver biopsies, which may have effected liver concentration of trace minerals at the time of biopsy. Additionally, all cows received adequate concentrations of trace minerals in the diet based on NRC (2001) requirements, which may be responsible for no statistical difference found in liver $\mathrm{Cu}$ concentration between treatments. Selenium is an important trace mineral necessary for many physiological functions and antioxidant defense systems (Sordillo, 2013). Selenium manifests itself in the innate immune response as selenocysteine, which is incorporated into selenoproteins by replacing protein sulfur residues (Sunde et al., 1997). Glutathione peroxidase is a primary antioxidant selenoprotein and functions to protect neutrophils during oxidative stress by reducing hydrogen peroxides to water (Rotruck et al., 1973; Sordillo, 2013). Teixeira et al. (2014) reported that calves supplemented with trace minerals had increased plasma GSH-Px activity compared with calves without supplementation. In the current study, plasma GSH-Px activity tended to increase for cows in MM compared with cows in POS. Additionally, we noted an upregulation in liver GPX1 expression for cows in POS compared with cows in both CON and MM. Bernabucci et al. (2011) reported that bovine blood peripheral mononuclear cell gene expression of GPX1 increased during an $\mathrm{AFB}_{1}$ challenge. This is similar to results in the current study; however, we found an upregulation in liver gene expression of GPX1 for cows in POS compared with those in MM. This indicates that cows in POS had an increased demand for GSH-Px synthesis to assist in the antioxidant defense system compared with those in MM. Previous research has revealed that increased serum Se concentration is correlated with increased GSH-Px activity in cattle (Koller et al., 1984). Although serum Se concentrations were not measured 
in the current study, Pogge et al. (2012) observed increased in serum Se concentrations and red blood cell GSH-Px activity in beef cattle when treated with trace mineral injection at $1 \mathrm{~mL} / 45 \mathrm{~kg}$ of BW. Additionally, Bittar et al. (2017) observed increased serum Se and $\mathrm{Mn}$ in dairy calves when treated with trace mineral injection at $1 \mathrm{~mL} / 45 \mathrm{~kg}$ of $\mathrm{BW}$. This suggests that cows receiving trace mineral injection had increased Se, which was used as a co-factor for GSH-Px production. Therefore, we propose that mineral injection has a positive effect by supplying cows with adequate trace mineral co-factor to increase antioxidant activity, primarily GSH-Px activity, during an AF challenge.

Alkaline phosphatase (ALP) is an inflammatoryrelated enzyme that uses zinc as a cofactor and is present in high concentrations in the liver (Naber et al., 1996; Beumer et al., 2003; Herdt and Hoff, 2011). Plasma ALP concentrations were greater for cows challenged with $\mathrm{AF}$ and receiving trace mineral injection compared with those without trace mineral injection. Weatherly et al. (2018) reported that cows receiving adsorbent (yeast cell wall + bentonite clay) had greater serum ALP concentrations (47.2 U/L) compared with cows without absorbent treatment $(38.1 \mathrm{U} / \mathrm{L})$ during an AF challenge. Increased plasma ALP concentrations have been attributed to liver dysfunction in cows undergoing heat stress (Kargar et al., 2015); however, in the present study, we observed no difference for plasma ALP concentration between cows with or without an aflatoxin challenge. Berrie et al. (1995) reported that lambs supplemented with Zn had increased serum ALP activity compared with lambs without $\mathrm{Zn}$ supplementation. Additionally, previous research showed that rats supplemented with Zn had higher ALP activity compared with rats without Zn supplementation (Naber et al., 1996). Therefore, we postulated that increased plasma ALP for cows in MM compared with cows in POS was due to supplementation of $\mathrm{Zn}$ from trace mineral injection rather than liver dysfunction.

Albumin is a negative acute phase protein, and its presence in blood is an indicator of liver functionality (Bertoni et al., 2008; Zhou et al., 2016). Previous studies have indicated that albumin plays an important role in $\mathrm{AFB}_{1}$ transport throughout the body (Evrain et al., 1978; Wild et al., 1992). Plasma albumin was increased for cows in POS compared with cows in both NEG and MM. These data may indicate an increased need for albumin-mediated transport of $\mathrm{AFB}_{1}$ for cows receiving an $\mathrm{AF}$ challenge compared with those with no AF challenge. However, it is important to note that albumin concentrations for all treatments were within normal bovine biological ranges (2.9-3.9 g/dL; Lumsden et al., 1980), and biological relevance of this outcome must be carefully evaluated.
Superoxide anion $\left(\mathrm{O}_{2}^{-}\right)$is a by-product of the oxidation of xanthine by xanthine oxidase during aerobic metabolism and increases in concentration during oxidative stress (McCord and Fridovich, 1968; Liddell et al., 2006). Superoxide anions and hydrogen peroxides have the capability to release Fe from ferritin, as well as other Fe-containing dehydratase enzymes, such as dihydroxy acid dehydratase, aconitase, and fumerases A and B, via inactivation (Williams et al., 1974; Liochev and Fridovich, 1999). Superoxide dismutases are dependent on either $\mathrm{Cu}^{-}, \mathrm{Mn}^{-}$, or $\mathrm{Zn}^{-}$and have been shown to decrease concentrations of intracellular $\mathrm{O}_{2}^{-}$by decreasing xanthine oxidation, consequently limiting iron release (Munday and Winterbourn, 1989; Reif, 1992). In addition, GSH-Px is responsible for disposal of peroxides, which are the product of SOD disproportionation of superoxide anion (Liddell et al., 2006; Sordillo, 2013). Weatherly et al. (2018) reported that cows receiving an AF challenge had greater concentrations of plasma SOD than cows not receiving an $\mathrm{AF}$. In the current study we found no difference in SOD activity among treatments.

Increased SOD concentrations in Weatherly et al. (2018) may have been due to the increased proportion of DMI as percentage of BW $[3.41 \%$ for cows not receiving $\mathrm{AF}(\mathrm{CON})$ and $3.39 \%$ for cows receiving $\mathrm{AF}$ (POS)] and, subsequently, proportion of AF intake by BW compared with the current experiment. Additionally, no difference between treatments was seen in the current study for SOD2 hepatic gene expression, which is an indicator of Mn-dependent SOD activity in the hepatic cytoplasm. No difference in SOD2 expression may have been due to acute AF exposure ( $3 \mathrm{~d}$ ), and increased duration of AF challenge may have elicited SOD2 expression changes. Two other isoforms of SOD have been identified and characterized in mammals (SOD1, Cu-Zn dependent; and SOD3, extracellular superoxide dismutase) that elicit similar functions to SOD2 (Miao and St. Clair, 2009). Further research is needed to fully understand the relationship among all isoforms and their co-factors, in different tissues, during the AF induced inflammatory process and their ability to scavenge $\mathrm{O}_{2}^{-}$.

However, as previously mentioned, we found increased activity of plasma GSH-Px for cows in MM compared with those in POS. Additionally, liver Fe concentration was decreased for cows in POS compared with cows in MM. These results could indicate that cows receiving an AF challenge and no trace mineral injection underwent greater oxidative stress than cows not receiving the trace mineral injection. However, the physiological relevance of these data must be evaluated with caution, as liver Fe concentrations for all treatments were within biological references ranges for healthy cows (140 to 
$100 \mu \mathrm{g} / \mathrm{g}$ of liver; Underwood and Suttle, 2014) and liver Fe differences may be due to changes in DMI.

\section{CONCLUSIONS}

Two subcutaneous injections of $15 \mathrm{mg} / \mathrm{mL}$ of $\mathrm{Cu}, 5$ $\mathrm{mg} / \mathrm{mL}$ of Se, $60 \mathrm{mg} / \mathrm{mL}$ of $\mathrm{Zn}$, and $10 \mathrm{mg} / \mathrm{mL}$ of $\mathrm{Mn}$ given at $1 \mathrm{~mL} / 90.7 \mathrm{~kg}$ of average $\mathrm{BW}$ to post-peak lactating multiparous Holstein cows during an AF challenge increased liver concentrations of Se and Fe as well as plasma ALP concentration. Trace mineral injection did not influence AF excretion in milk during an $\mathrm{AF}$ challenge; however, decreased MUN, serum BUN, and liver GPX1 expression, as well as increased serum GSHPx activity, for cows treated with trace mineral injection indicated a positive antioxidant response when an AF challenge was present. The effects of trace mineral injections in cows exposed to a prolonged $\mathrm{AF}$ challenge (e.g.; the duration of the experimental period instead of a bolus) on blood and liver inflammatory markers are still to be determined. Other mycotoxins of biological relevance [e.g., deoxynivalenol (vomotoxin)] and classified as carcinogens also deserve attention.

\section{ACKNOWLEDGMENTS}

This project was partially supported by Multimin North America (Fort Collins, Co). We thank Ajinomoto Heartland, Inc. (Chicago, IL) for the donation of Ajipro-L Generation 2 and Adisseo (Alpharretta, GA) for the donation of Smartamine M during the course of the experiment. Special appreciation is extended to the Dairy Focus Team at the University of Illinois, along with the University of Illinois Dairy Research Unit staff for helping with data collection and cow care.

\section{REFERENCES}

Abrar, M., F. M. Anjum, M. S. Butt, I. Pasha, M. A. Randhawa, F. Saeed, and K. Waqas. 2013. Aflatoxins: Biosynthesis, occurrence, toxicity, and remedies. Crit. Rev. Food Sci. Nutr. 53:862-874.

AOAC International. 1995a. Official method 934.01. Moisture in animal feed. Pages 23-26 in Official Methods of Analysis. 16th ed. Vol. 2. AOAC International, Arlington, VA.

AOAC International. 1995b. Official method 972.16. Fat, lactose, protein, and solids in milk. Mid-infrared spectroscopic method. Pages 23-26 in Official Methods of Analysis. 16th ed. Vol. 2. AOAC International, Arlington, VA.

Baker, R. G., M. S. Hayden, and S. Ghosh. 2011. NF-кB, inflammation, and metabolic disease. Cell Metab. 13:11-22.

Bernabucci, U., L. Colavecchia, P. P. Danieli, L. Basiricò, N. Lacetera, A. Nardone, and B. Ronchi. 2011. Aflatoxin B1 and fumonisin B1 affect the oxidative status of bovine peripheral blood mononuclear cells. Toxicol. In Vitro 25:684-691.

Berrie, R. A., D. M. Hallford, M. L. Galyean, A. L. Brundage, and T. W. White. 1995. Effects of zinc source and level on performance, carcass characteristics, and metabolic hormone concentrations of growing and finishing lambs. Prof. Anim. Sci. 11:149-156.
Bertoni, G., E. Trevisi, X. Han, and M. Bionaz. 2008. Effects of inflammatory conditions on liver activity in puerperium period and consequences for performance in dairy cows. J. Dairy Sci. 91:33003310 .

Beumer, C., M. Wulferink, W. Raaben, D. Fiechter, R. Brands, and W. Seinen. 2003. Calf intestinal alkaline phosphatase, a novel therapeutic drug for lipopolysaccharide (LPS)-mediated diseases, attenuates LPS toxicity in mice and piglets. J. Pharmacol. Exp. Ther. 307:737.

Bittar, J. H., D. J. Hurley, A. R. Woolums, N. A. Norton, C. E. Barber, F. Moliere, L. J. Havenga, and R. A. Palomares. 2017. Effects of injectable trace minerals on the immune response to Mannheimia haemolytica and Pasteurella multocida following vaccination of dairy calves with a commercial attenuated-live bacterin vaccine. Prof. Anim. Sci. 34:59-66.

Drackley, J. K. 1999. Biology of dairy cows during the transition period: The final frontier? J. Dairy Sci. 82:2259-2273.

Evrain, C., N. Cittanova, and M. F. Jayle. 1978. Fluorescence studies of the interactions of serum albumin and rat alpha1-fetoprotein with aflatoxin B1: Specificity and binding parameters. Biochim. Biophys. Acta 533:408-414.

Ferguson, J. D., D. T. Galligan, and N. Thomsen. 1994. Principa descriptors of body condition score in Holstein cows. J. Dairy Sci. $77: 2695-2703$

Flores-Flores, M. E., E. Lizarraga, A. López de Cerain, and E. González-Peñas. 2015. Presence of mycotoxins in animal milk: A review. Food Control 53:163-176.

Gao, S. T., J. Guo, S. Y. Quan, X. M. Nan, M. V. Sanz Fernandez, L. H. Baumgard, and D. P. Bu. 2017. The effects of heat stress on protein metabolism in lactating Holstein cows. J. Dairy Sci. 100:5040-5049.

Genther, O. N., and S. L. Hansen. 2014. Effect of dietary trace mineral supplementation and a multi-element trace mineral injection on shipping response and growth performance of beef cattle. J. Anim. Sci. 92:2522-2530.

Guengerich, F. P., H. Cai, M. McMahon, J. D. Hayes, T. R. Sutter, J. D. Groopman, Z. Deng, and T. M. Harris. 2001. Reduction of aflatoxin B1 dialdehyde by rat and human aldo-keto reductases. Chem. Res. Toxicol. 14:727-737.

Herdt, T. H., and B. Hoff. 2011. The use of blood analysis to evaluate trace mineral status in ruminant livestock. Vet. Clin. North Am. Food Anim. Pract. 27:255-283.

Ireland-Perry, R. L., and C. Stallings. 1993. Fecal consistency as related to dietary composition in lactating Holstein cows. J. Dairy Sci. 76:1074-1082.

Kargar, S., G. R. Ghorbani, V. Fievez, and D. J. Schingoethe. 2015. Performance, bioenergetic status, and indicators of oxidative stress of environmentally heat-loaded Holstein cows in response to diets inducing milk fat depression. J. Dairy Sci. 98:4772-4784.

Khan, M. J., C. B. Jacometo, M. Vailati Riboni, E. Trevisi, D. E Graugnard, M. N. Corrêa, and J. J. Loor. 2015. Stress and inflammatory gene networks in bovine liver are altered by plane of dietary energy during late pregnancy. Funct. Integr. Genomics 15:563-576.

Kincaid, R. L. 2000. Assessment of trace mineral status of ruminants: A review. J. Anim. Sci. 77:1-10.

Koller, L. D., P. J. South, J. H. Exon, G. A. Whitbeck, and J. Maas. 1984. Comparison of selenium levels and glutathione peroxidase activity in bovine whole blood. Can. J. Comp. Med. 48:431-433.

Kononoff, P. J., A. Heinrichs, and D. Buckmaster. 2003. Modification of the Penn State forage and total mixed ration particle separator and the effects of moisture content on its measurements. J. Dairy Sci. 86:1858-1863.

Krause, K. M., D. Dhuyvetter, and G. Oetzel. 2009. Effect of a lowmoisture buffer block on ruminal $\mathrm{pH}$ in lactating dairy cattle induced with subacute ruminal acidosis. J. Dairy Sci. 92:352-364.

Krause, K. M., and G. Oetzel. 2005. Inducing subacute ruminal acidosis in lactating dairy cows. J. Dairy Sci. 88:3633-3639.

Kuilman, M. E. M., R. F. M. Maas, and J. Fink-Gremmels. 2000. Cytochrome P450-mediated metabolism and cytotoxicity of aflatoxin B1 in bovine hepatocytes. Toxicol. In Vitro 14:321-327. 
Kutz, R. E., J. Sampson, L. Pompeu, D. Ledoux, J. Spain, M. VazquezAnon, and G. Rottinghaus. 2009. Efficacy of Solis, NovasilPlus, and MTB-100 to reduce aflatoxin M1 levels in milk of early to midlactation dairy cows fed aflatoxin B1. J. Dairy Sci. 92:3959-3963.

Liddell, J. R., H. H. Hoepken, P. J. Crack, S. R. Robinson, and R. Dringen. 2006. Glutathione peroxidase 1 and glutathione are required to protect mouse astrocytes from iron-mediated hydrogen peroxide toxicity. J. Neurosci. Res. 84:578-586.

Liochev, S. I., and I. Fridovich. 1999. Superoxide and iron: Partners in crime. IUBMB Life 48:157-161.

Littell, R. C. 2002. Analysis of unbalanced mixed model data: a case study comparison of ANOVA versus REML/GLS. J. Agric. Biol. Environ. Stat. 7:472-490.

Liu, Y., and F. Wu. 2010. Global burden of aflatoxin-induced hepatocellular carcinoma: A risk assessment. Environ. Health Perspect. 118:818-824.

Lumsden, J. H., K. Mullen, and R. Rowe. 1980. Hematology and biochemistry reference values for female Holstein cattle. Can. J. Comp. Med. 44:24-31.

Machado, V. S., G. Oikonomou, S. Lima, M. Bicalho, C. Kacar, C. Foditsch, M. Felippe, R. Gilbert, and R. Bicalho. 2014. The effect of injectable trace minerals (selenium, copper, zinc, and manganese) on peripheral blood leukocyte activity and serum superoxide dismutase activity of lactating Holstein cows. Vet. J. 200:299-304.

Machado, V. S., M. L. S. Bicalho, R. V. Pereira, L. S. Caixeta, W. A Knauer, G. Oikonomou, R. O. Gilbert, and R. C. Bicalho. 2013. Effect of an injectable trace mineral supplement containing selenium, copper, zinc, and manganese on the health and production of lactating Holstein cows. Vet. J. 197:451-456.

Maki, C. R., A. Thomas, S. Elmore, A. Romoser, R. Harvey, H. Ramirez-Ramirez, and T. Phillips. 2016. Effects of calcium montmorillonite clay and aflatoxin exposure on dry matter intake, milk production, and milk composition. J. Dairy Sci. 99:1039-1046.

McCord, J. M., and I. Fridovich. 1968. The reduction of cytochrome c by milk xanthine oxidase. J. Biol. Chem. 243:5753-5760.

Miao, L., and D. K. St. Clair. 2009. Regulation of Superoxide Dismutase Genes: Implications in Diseases. Free Radic. Biol. Med. $47: 344-356$.

Mitchell, N. J., E. Bowers, C. Hurburgh, and F. Wu. 2016. Potential economic losses to the USA corn industry from aflatoxin contamination. Food Addit. Contam. Part A Chem. Anal. Control Expo. Risk 33:540-550.

Moschini, M., A. Gallo, G. Piva, and F. Masoero. 2008. The effects of rumen fluid on the in vitro aflatoxin binding capacity of different sequestering agents and in vivo release of the sequestered toxin. Anim. Feed Sci. Technol. 147:292-309.

Mulligan, F. J., L. O'Grady, D. A. Rice, and M. L. Doherty. 2006. A herd health approach to dairy cow nutrition and production diseases of the transition cow. Anim. Reprod. Sci. 96:331-353.

Munday, R., and C. C. Winterbourn. 1989. Reduced glutathione in combination with superoxide dismutase as an important biological antioxidant defense mechanism. Biochem. Pharmacol. 38:43494352.

Naber, T. H. J., H. Baadenhuysen, J. B. M. J. Jansen, C. J. A. van den Hamer, and W. van den Broek. 1996. Serum alkaline phosphatase activity during zinc deficiency and long-term inflammatory stress. Clin. Chim. Acta 249:109-127.

NRC. 2001. Nutrient Requirements of Dairy Cattle. 7th rev. ed. Natl. Acad. Press, Washington, DC.

Ogunade, I. M., K. G. Arriola, Y. Jiang, J. P. Driver, C. R. Staples, and A. T. Adesogan. 2016. Effects of 3 sequestering agents on milk aflatoxin $\mathrm{M}_{1}$ concentration and the performance and immune status of dairy cows fed diets artificially contaminated with aflatoxin $B_{1}$. J. Dairy Sci. 99:6263-6273.

Pearce, S. C., M.-V. Sanz Fernandez, J. Torrison, M. E. Wilson, L. H. Baumgard, and N. K. Gabler. 2015. Dietary organic zinc attenuates heat stress-induced changes in pig intestinal integrity and metabolism. J. Anim. Sci. 93:4702-4713.
Peraica, M., B. Radić, A. Lucić, and M. Pavlović. 1999. Toxic effects of mycotoxins in humans. Bull. World Health Organ. 77:754-766.

Pogge, D. J., E. L. Richter, M. E. Drewnoski, and S. L. Hansen. 2012. Mineral concentrations of plasma and liver after injection with a trace mineral complex differ among Angus and Simmental cattle. J. Anim. Sci. 90:2692-2698.

Reif, D. W. 1992. Ferritin as a source of iron for oxidative stress. Free Radic. Biol. Med. 12:417-427.

Rotruck, J. T., A. L. Pope, H. E. Ganther, A. B. Swanson, D. G. Hafeman, and W. G. Hoekstra. 1973. Selenium: Biochemical role as a component of glutathione peroxidase. Science 179:588.

Shi, J., J. He, J. Lin, X. Sun, F. Sun, C. Ou, and C. Jiang. 2016. Distinct response of the hepatic transcriptome to Aflatoxin $\mathrm{B}_{1}$ induced hepatocellular carcinogenesis and resistance in rats. Sci. Rep. 6:31898.

Sordillo, L. M. 2013. Selenium-dependent regulation of oxidative stress and immunity in periparturient dairy cattle. Vet. Med. Int 2013:154045.

Spears, J. W., and W. P. Weiss. 2008. Role of antioxidants and trace elements in health and immunity of transition dairy cows. Vet. J. 176:70-76.

Sulzberger, S. A., S. Melnichenko, and F. Cardoso. 2017. Effects of clay after an aflatoxin challenge on aflatoxin clearance, milk production, and metabolism of Holstein cows. J. Dairy Sci. 100:18561869.

Sunde, R. A., B. M. Thompson, M. D. Palm, S. L. Weiss, K. M. Thompson, and J. K. Evenson. 1997. Selenium regulation of selenium-dependent glutathione peroxidases in animals and transfected CHO cells. Biomed. Environ. Sci. 10:346-355.

Teixeira, A. G. V., F. S. Lima, M. L. S. Bicalho, A. Kussler, S. F. Lima, M. J. Felippe, and R. C. Bicalho. 2014. Effect of an injectable trace mineral supplement containing selenium, copper, zinc, and manganese on immunity, health, and growth of dairy calves. J. Dairy Sci. 97:4216-4226.

Vailati Riboni, M. V., S. Meier, N. V. Priest, C. R. Burke, J. K. Kay, S. McDougall, M. D. Mitchell, C. G. Walker, M. Crookenden, A. Heiser, J. R. Roche, and J. J. Loor. 2015. Adipose and liver gene expression profiles in response to treatment with a nonsteroidal antiinflammatory drug after calving in grazing dairy cows. J. Dairy Sci. 98:3079-3085.

Underwood, E. J., and N. F. Suttle. 2014. The Mineral Nutrition of Livestock. 4th ed. CABI Publishing, New York, NY

Vanegas, J. A., J. Reynolds, and E. R. Atwill. 2004. Effects of an injectable trace mineral supplement on first-service conception rate of dairy cows. J. Dairy Sci. 87:3665-3671.

Weatherly, M. E., R. T. Pate, G. E. Rottinghaus, F. O. Roberti Filho, and F. C. Cardoso. 2018. Physiological responses to a yeast and clay-based adsorbent during an aflatoxin challenge in Holstein cows. Anim. Feed Sci. Technol. 235:147-157.

Wild, C. P., G. J. Hudson, G. Sabbioni, B. Chapot, A. J. Hall, G. N. Wogan, H. Whittle, R. Montesano, and J. D. Groopman. 1992. Dietary intake of aflatoxins and the level of albumin-bound aflatoxin in peripheral blood in The Gambia, West Africa. Cancer Epidemiol. Biomarkers Prev. 1:229.

Williams, D. M., G. R. Lee, and G. E. Cartwright. 1974. The role of superoxide anion radical in the reduction of ferritin iron by xanthine oxidase. J. Clin. Invest. 53:665-667.

Xiong, J. L., Y. Wang, T. Nennich, Y. Li, and J. Liu. 2015. Transfer of dietary aflatoxin B1 to milk aflatoxin M1 and effect of inclusion of adsorbent in the diet of dairy cows. J. Dairy Sci. 98:2545-2554.

Zhou, Z., O. Bulgari, M. Vailati-Riboni, E. Trevisi, M. A. Ballou, F C. Cardoso, D. N. Luchini, and J. J. Loor. 2016. Rumen-protected methionine compared with rumen-protected choline improves immunometabolic status in dairy cows during the peripartal period. J. Dairy Sci. 99:8956-8969. 